Check for updates

Cite this: RSC Adv., 2017, 7, 54281

Received 13th October 2017

Accepted 20th November 2017

DOI: 10.1039/c7ra11273d

rsc.li/rsc-advances

\section{Combined effect of tris(2-chloroethyl)phosphate and benzo (a) pyrene on the release of IL-6 and IL-8 from HepG2 cells via the EGFR-ERK1/2 signaling pathway}

\author{
Youjian Zhang, (D) ab Wenjuan Zhang, ${ }^{\text {ab }}$ Jian Hou, (D) ab Xian Wang, ${ }^{\text {ab }}$ Hongyan Zheng, ${ }^{\text {ab }}$ \\ Wei Xiong ${ }^{\text {ab }}$ and Jing Yuan (D) *ab
}

Tris(2-chloroethyl)phosphate (TCEP) and benzo (a) pyrene (BaP) coexist in the environment. Humans are exposed to them via multiple routes every day. Each of them induces hepatotoxicity, which may increase their risk to human health. However, the mechanism underlying the combined toxicity of both compounds in vitro is still unclear. The present study aimed to investigate the molecular mechanism underlying the inflammatory response in the cotreatment of HepG2 cells with TCEP and BaP. The cell viability, and the expression of interleukin (IL)- 6 and IL- 8 at the mRNA and protein levels were measured in HepG2 cells. The results indicated that TCEP plus BaP decreased HepG2 cell viability, and upregulated the expression of IL- 6 and IL- 8 at the mRNA and protein levels. Additionally, the inhibitors of EGFR (AG1478), ERK1/2 (U0126) and p38 MAPK (SB203580) displayed anti-inflammatory properties in the inflammatory response elicited by TCEP plus BaP. The activation of ERK1/2, but not p38 MAPK was inhibited by AG1478. These results indicated that TCEP plus BaP may induce an inflammatory response in HepG2 cells by the activation of the EGFR-ERK1/2 signaling pathway.

\section{Introduction}

Tris(2-chloroethyl)phosphate (TCEP) as an organophosphorus flame retardant has been widely used in a variety of commercial products, including textiles, furniture and electronic devices. Benzo (a) pyrene (BaP) is often used as a toxicological prototype or surrogate for carcinogenic polycyclic aromatic hydrocarbons because it is the most studied carcinogenic polycyclic aromatic hydrocarbon and a known animal carcinogen and a probable human carcinogen according to the International Agency for Research on Cancer classification. ${ }^{1}$ The consumption of BaPcontaining foods is the major route for human BaP exposure, ${ }^{2}$ in addition to smoking tobacco, inhalation of polluted air and ingestion of water contaminated by $\mathrm{BaP} .{ }^{1}$ Several recent studies showed that TCEP coexists with BaP in the atmosphere, ${ }^{3}$ surface water $^{4}$ and fish. ${ }^{5}$ Thus, there is a potential risk for humans to be exposed to low concentrations of TCEP and BaP via food intake, drinking water and air inhalation.

\footnotetext{
${ }^{a}$ Department of Occupational and Environmental Health, Tongji Medical College, Huazhong University of Science and Technology, Wuhan 430030, Hubei, P. R. China.E-mail:jyuan@tjh.tjmu.edu.cn; Fax: +86 27 83657765; Tel: +86 2783693209 ${ }^{b}$ Key Laboratory of Environment and Health, Ministry of Education \& Ministry of Environmental Protection, State Key Laboratory of Environmental Health (Incubating), School of Public Health, Tongji Medical College, Huazhong University of Science and Technology, Wuhan 430030, Hubei, P. R. China
}

The liver is a major organ for TCEP and BaP metabolisms. These two compounds have individually shown to cause hepatotoxicity. For instance, the microscopic examination revealed that the incidence of altered eosinophilic foci was increased in a dose-dependent manner in the livers of male B6C3F1 mice after 2 years treatment with TCEP (175 and $350 \mathrm{mg} \mathrm{kg}^{-1}$ day $\left.^{-1}\right){ }^{6}$ implying that TCEP may initiate the inflammatory response in the livers. The evidence showed that BaP induced liver inflammation in Kunming strain mice. ${ }^{7}$ The releases of proinflammatory cytokines interleukin (IL)-6 and IL-8 involved in the developments of multiple inflammatory diseases were associated with exposure of environmental pollutants. The in vivo study showed that BaP at a lower dose induced allergic airway inflammation in $\mathrm{C} 3 \mathrm{H} / \mathrm{HeJ}$ mice. ${ }^{8}$ An epidemiological study found that the prevalences of asthma and allergic rhinitis were associated tributyl phosphate in floor dust. ${ }^{9}$ In vivo and in vitro studies suggested that inflammatory mediators (including interleukins and tumor necrosis factor- $\alpha$ ) played a vital role in the development of human liver, lung and colon tumors induced by BaP. ${ }^{10}$

Most of the studies conducted are focused on singlechemical toxicity. However, various kinds of compounds coexist in the environments such as TCEP and BaP are not only mixed with each other, but also synergistically interacted with each other. ${ }^{11,12}$ Therefore, to identify and assess human health risk of environmental pollutants, it is imperative to investigate 
combined effects of environmental pollutants on human health and the relevant underlying mechanisms.

The mitogen-activated protein kinase (MAPK)-signaling cascades, including extracellular signal-regulated kinase (ERK), p38 MAPK and c-Jun NH2-terminal kinase (JNK), they are essential for cell-fate processes, including inflammation, cell stress response, cell differentiation, cell proliferation and death. The evidence showed that the MAPK signaling pathway mainly modified inflammatory response to environmental stress, including fine particulate matter $\left(\mathrm{PM}_{2.5}\right.$, particulates with an aerodynamic diameter $\leq 2.5 \mu \mathrm{m}),{ }^{13}$ bisphenol $\mathrm{A}^{14}$ and ozone. ${ }^{15}$ Several studies suggested that the MAPK signaling pathway was coupled to the epidermal growth factor receptor (EGFR). ${ }^{16,17}$

EGFR was a cell surface receptor for members of the epidermal growth factor family (EGF-family) of extracellular protein ligands. In addition to being activated by growth factors such as EGF and platelet-derived growth factor ${ }^{18}$ EGFR was also activated by various environmental pollutants, such as hexachlorobenzene ${ }^{19}$ and fine particulate matter. ${ }^{13}$ Over-activated EGFR signaling was related to a variety of signals that increased cell proliferation or inhibit cell apoptosis. ${ }^{20,21}$ EGFR signaling pathways not only promoted cell survival and proliferation, ${ }^{22}$ but regulated inflammatory response along with cytokine secretions (such as IL-6 and IL-8) after exposure to cigarette smoke or $\mathrm{PM}_{2.5}{ }^{13,23}$ However, it is still unknown whether EGFR and MAPKs participated in inflammatory response in HepG2 cells co-treated with TCEP and BaP.

BaP parent compound was mainly metabolized in the liver by cytochrome P 450 enzymes and then exert various toxicities. ${ }^{24}$ HepG2 cells showed more similarity to human liver than the other cell lines in the inductions of CYP450 enzymes, such as CYP1A1 and CYP3A4. ${ }^{25}$ HepG2 cells are of the advantage of stronger metabolic capacity for xenobiotic compounds and commonly used in toxicological studies. ${ }^{26,27}$ Therefore, in this study, HepG2 cells as a test system were used to determine the toxicity of co-treatment of TCEP and BaP.

Based on the clues above, we hypothesized that co-treatment of TCEP and BaP initiated inflammation in HepG2 cells, which modulated through the EGFR-MAPK signaling pathway.

\section{Materials and methods}

\subsection{Chemicals and reagents}

Dimethyl sulfoxide (DMSO), 3-(4,5-dimethyithiazol-2-yl)-2,5diphenyl-tetrazolium bromide (MTT), TCEP (CAS no. 115-96-8, purity: 97\%) and BaP (CAS no. 50-32-8, purity: 96\%) were obtained from Sigma-Aldrich Inc. (St. Louis, Missouri, USA). Dulbecco's Modified Eagle Medium (DMEM) and fetal bovine serum (FBS) were purchased from Thermo Fisher Scientific Inc. (Waltham, Massachusetts, USA). Human IL-6 kit (catalog no. EK-1062) and IL-8 ELISA kit (catalog no. EK-1082) were purchased from MultiScience Company (Hangzhou, China). RNA extraction by using RNAprep pure cell kit (catalog no. DP430) from Tiangen Biotech Co., Ltd (Beijing, China). Firststrand cDNA synthesis was performed by using a first-strand cDNA synthesis kit (catalog no. K1622) by using an oligo-dT primer. The SYBR ${ }^{8}$ fast qPCR master mix $(2 \times)$ kit (catalog no. KK4604) (Kapa Biosystems Inc., Wilmington, Massachusetts, USA).

The following primary rabbit monoclonal antibodies (Dilution: $1: 1000$, Cell Signaling Technology, Inc. Beverly, Massachusetts, USA) were used: phospho-EGFR (Tyr1068) (catalog no. 3777), total EGFR (catalog no. 4267), phospho-ERK1/2 (T202/ Y204) (catalog no. 4370), total ERK1/2 (catalog no. 4695), phospho-p38 MAPK (Thr180/Tyr182) (catalog no. 4511), total p38 MAPK (catalog no. 8690). Primary mouse GAPDH polyclonal antibody (dilution: $1: 10$ 000, catalog no. AP0063), goat antirabbit immunoglobulin (Ig) G-horseradish peroxidase (dilution: $1: 5000$, catalog no. BS13278) and goat anti-mouse IgGhorseradish peroxidase (dilution: 1:5000, catalog no. BS12478) were obtained from Bioworld Technology Co., Ltd., MN, USA. The inhibitors (AG1478, U0126 and SB203580) were purchased from Cell Signaling Technology, Inc.

\subsection{Cell culture and treatments}

The human hepatoma HepG2 cells were obtained from the Cell Bank of Type Culture Collection of Chinese Academy of Science (Shanghai, China), and maintained in DMEM medium containing $10 \% \mathrm{FBS}$ at $37{ }^{\circ} \mathrm{C}$ in a $5 \% \mathrm{CO}_{2}$ humidified atmosphere. When the cells grew to $70 \%$ confluence, the media were replaced by the fresh media consisting of TCEP $(3.12,12.5,50$ and $\left.200 \mathrm{mg} \mathrm{L}^{-1}\right)$ or/and BaP $(50 \mu \mathrm{M})$ as well as of $0.1 \%$ DMSO ( $\mathrm{v} / \mathrm{v}$, solvent control) for 24 and $48 \mathrm{~h}$. In addition, AG1478 (EGFR inhibitor), U0126 (MEK/ERK inhibitor) and SB203580 (p38 MAPK inhibitor) were dissolved in DMSO, the final concentrations of these inhibitors were $0.1,10$ and $10 \mu \mathrm{M}$, respectively. According to the reported concentrations of AG1478, U0126 or SB203580, ${ }^{28,29}$ the same concentrations of them were used in this study and did not find the effects on the HepG2 cell viability by MTT assay (data not shown). HepG2 cells were pretreated with AG1478, U0126 or SB203580 for $1 \mathrm{~h}$ and then co-incubated with TCEP $\left(50 \mathrm{mg} \mathrm{L}^{-1}\right)$ or/and BaP $(50 \mu \mathrm{M})$ for $24 \mathrm{~h}$.

\section{$2.3 \quad$ MTT assay}

MTT assay was used to measured effects of TCEP or/and BaP on cellular viability. Briefly, cells were seeded in 96-well microtiter plates at a density of 5000 cells per well and allowed to growth for $24 \mathrm{~h}$, and then treated with $100 \mu \mathrm{L}$ of the fresh culture medium containing the indicated concentrations of TCEP or/ and BaP. After 24 and $48 \mathrm{~h}$ of incubation, $10 \mu \mathrm{L}$ of MTT stock solution ( $5 \mathrm{mg} \mathrm{mL}^{-1}$ in sterile PBS) was added to each well for an additional $4 \mathrm{~h}$ of incubation at $37^{\circ} \mathrm{C}$. A volume of $150 \mu \mathrm{L}$ DMSO was added to each well to terminate the MTT reaction. After shaking gently the plates for $10 \mathrm{~min}$, the optical density of each well was measured at $570 \mathrm{~nm}$ using a microplate reader (BioTek Instruments Inc., Winooski, Vermont, USA). Six replicates of at least three independent experiments were performed. The results were presented as the mean \pm SD.

\section{4 qRT-PCR analysis}

qRT-PCR analysis was used to determine effects of TCEP or/and BaP on IL-6 and IL-8 mRNA expression. Briefly, HepG2 cells 
were seeded onto 6-well plates at a density of $1.5 \times 10^{5}$ cells per well for $24 \mathrm{~h}$, and then subsequently treated either with TCEP alone $\left(3.12,12.5,50\right.$ and $\left.200 \mathrm{mg} \mathrm{L}^{-1}\right), 50 \mu \mathrm{M}$ BaP alone and TCEP at the indicated concentrations plus $50 \mu \mathrm{M}$ BaP for 24 and $48 \mathrm{~h}$, or pretreated with AG1478, U0126 or SB203580 for $1 \mathrm{~h}$ prior to the treatment of $50 \mathrm{mg} \mathrm{L^{-1 }}$ TCEP alone, $50 \mu \mathrm{M} \mathrm{BaP}$ alone or $50 \mathrm{mg} \mathrm{L}^{-1}$ TCEP plus $50 \mu \mathrm{M}$ BaP for $24 \mathrm{~h}$. Total RNA was isolated using RNAprep pure cell kit (Tiangen Biotech Co., Ltd., Beijing, China). One microgram RNA was reversetranscribed using first-strand cDNA synthesis kit (Thermo Fisher Scientific Inc., Waltham, Massachusetts, USA). The sequences of primers used in the qRT-PCR assay were as follows: IL-6 (forward primer, 5'-CACACAGACAGCCACTCACC$3^{\prime}$; reverse primer, 5'-AGTGCCTCTTTGCTGCTTTC-3'), IL-8 (forward primer, 5'-GACTTTCGCTCTCCATCCAC-3'; reverse primer, $5^{\prime}$-TGAATTCTCAGCCCTCTTCAA- $3^{\prime}$ ), GAPDH (forward primer, $5^{\prime}$-ACCCAGAAGACTGTGGATGG-3'; reverse primer, $5^{\prime}$ TTCAGCTCAGGGATGACCTT- $3^{\prime}$ ). The qRT-PCR was performed using the $\mathrm{SYBR} \AA$ fast $\mathrm{qPCR}$ master mix $(2 \times)$ kit (Kapa Biosystems Inc., Wilmington, Massachusetts, USA). Each reaction consisted of $5 \mu \mathrm{L}$ of SYBR® qPCR master mix $(2 \times), 0.2 \mu \mathrm{L}$ of each primer $(10 \mu \mathrm{M}), 1 \mu \mathrm{l}$ of the cDNA product, and $3.6 \mu \mathrm{L}$ PCRgrade water. The qRT-PCR reactions were performed, using the ABI 7900 HT Fast Real Time PCR system (Applied Biosystem, Foster City, California, USA), under the following conditions: initial denaturation step at $95^{\circ} \mathrm{C}$ for $3 \mathrm{~min}$, followed by 40 cycles of denaturation at $95{ }^{\circ} \mathrm{C}$ for $15 \mathrm{~s}$, and annealing extension at $60{ }^{\circ} \mathrm{C}$ for $60 \mathrm{~s}$. The dissociation curves were constructed and used to detect nonspecific amplified products.

\subsection{ELISA assay}

Enzyme-linked immunosorbent assay (ELISA) was performed to determine IL-6 and IL-8 proteins in the cell culture media using the ELISA kits (MultiScience Company, Hangzhou, China) according to the manufacturer's instruction. Briefly, HepG2 cells were seeded onto 6-well plates at a density of $1.5 \times 10^{5}$ cells per well for $24 \mathrm{~h}$, and treated either with TCEP alone $(3.12,12.5$, 50 and $\left.200 \mathrm{mg} \mathrm{L}^{-1}\right)$, BaP alone $(50 \mu \mathrm{M})$ and TCEP at the indicated concentrations plus BaP for 24 and $48 \mathrm{~h}$, or pretreated with AG1478, U0126 or SB203580 for $1 \mathrm{~h}$ prior to the treatment of $50 \mathrm{mg} \mathrm{L}^{-1}$ TCEP alone, $50 \mu \mathrm{M}$ BaP alone or $50 \mathrm{mg} \mathrm{L}^{-1}$ TCEP plus $50 \mu \mathrm{M}$ BaP for $24 \mathrm{~h}$. The collected culture supernatants were stored at $-20{ }^{\circ} \mathrm{C}$ for measurements of IL-6 and IL-8 proteins. The cells were scraped and lysed to obtain the total protein. The productions of IL- 6 and IL- 8 were expressed as nanogram per gram of total protein. Data were presented as the mean \pm SD of three independent experiments.

\subsection{Western blotting}

To reveal the modulations of the EGFR and MAPK signaling pathways in inflammatory response in HepG2 cells treated with TCEP alone, BaP alone and both of them, involvements of proteins in the two signaling pathways were measured. Briefly, cells were seeded in $60 \mathrm{~mm}$ Petri dishes at a density of $5 \times 10^{5}$ cells per dish for $24 \mathrm{~h}$, and then treated either with TCEP alone $\left(3.12,12.5,50\right.$ and $\left.200 \mathrm{mg} \mathrm{L}^{-1}\right), 50 \mu \mathrm{M}$ BaP alone or TCEP at the indicated concentrations plus $50 \mu \mathrm{M} \mathrm{BaP}$ for 24 and $48 \mathrm{~h}$. Additionally, to confirm the downstream effectors of the EGFR signaling pathway, HepG2 cells were pretreated with AG1478 for $1 \mathrm{~h}$ prior to the treatment of $50 \mathrm{mg} \mathrm{L}^{-1}$ TCEP alone, $50 \mu \mathrm{M} \mathrm{BaP}$ alone or both of them for $24 \mathrm{~h}$. Subsequently, the cells were lysed on ice with $0.1 \mathrm{~mL}$ radio immunoprecipitation assay (RIPA) lysis buffer (Beyotime institute of biotechnology Haimen, Jiangsu, China) containing $1 \mathrm{mM}$ phenylmethylsulfonyl fluoride containing (PMSF, Beyotime institute of biotechnology, Haimen, Jiangsu, China) and 1\% phosphatase inhibitors (Cell Signaling Technology, Inc. Danvers, Massachusetts, USA). The lysate were centrifuged at $20000 \mathrm{~g}$ for $15 \mathrm{~min}$ to collect the resulting supernatants. Protein concentrations were determined using the Pierce ${ }^{\mathrm{TM}}$ BCA Protein Assay Kit (Thermo Fisher Scientific Inc., Massachusetts, USA). The 10\% sodium dodecyl sulfate-polyacrylamide gel electrophoresis (SDS-PAGE) were used for the separation of proteins samples. Subsequently, the proteins were electrotransferred onto polyvinylidene difluoride membranes $(0.22 \mu \mathrm{m}$, Millipore Inc., Billerica, Massachusetts, USA). These membranes were incubated with the appropriate rabbit monoclonal antibodies of phospho-EGFR, total EGFR, phospho-ERK1/2, total ERK1/2, phospho-p38 MAPK, total p38 MAPK and mouse GAPDH polyclonal antibody for overnight. Thereafter, the membranes were washed 3 times $(10$ min per wash) and treated with horseradish peroxidase - conjugated goat anti-rabbit or anti-mouse IgG antibody at room temperature for $2 \mathrm{~h}$. The specific proteins were visualized using an ECL detection system. The signals of bands were visualized using the GeneGnome imaging system (Syngene Bio Imaging, Cambridge, UK). The intensity of each protein band was quantified using the GeneTool software (Syngene Bio Imaging, Cambridge, UK). Results were presented as the mean \pm SD of three independent experiments.

\subsection{Statistical analysis}

Data were analyzed by one-way analysis of variance (ANOVA) with subsequent Dunnett's multiple comparison post hoc test using the SPSS statistical package 12.0 (SPSS Inc., Chicago, IL, USA). Significant difference was considered when $P<0.05$.

\section{Results}

\subsection{Combined effect of TCEP and BaP on cell viability}

To investigate the degree of cytotoxicity of HepG2 cells cotreated with TCEP and BaP, we measured cell viability using the MTT assay. As shown in Fig. 1, cell viability was dramatically decreased in the groups of $200 \mathrm{mg} \mathrm{L}^{-1}$ TCEP alone and cotreated groups with TCEP $\left(3.12,12.5,50\right.$ or $\left.200 \mathrm{mg} \mathrm{L}^{-1}\right)$ plus $50 \mu \mathrm{M} \mathrm{BaP}$ at 24 and $48 \mathrm{~h}$, compared to the solvent control $(* * P<0.01)$. A dramatically decrease in cell viability was observed in the group of $200 \mathrm{mg} \mathrm{L}^{-1}$ TCEP plus $50 \mu \mathrm{M}$ BaP at 24 and $48 \mathrm{~h}$, compared to the group of $50 \mu \mathrm{M}$ BaP alone $\left({ }^{\# \#} P<0.01\right)$. Compared to the corresponding groups of TCEP alone, all the co-treated groups of TCEP plus BaP decreased the cell viability at 24 and $48 \mathrm{~h}(P<0.05$ or $P<0.01)$. 


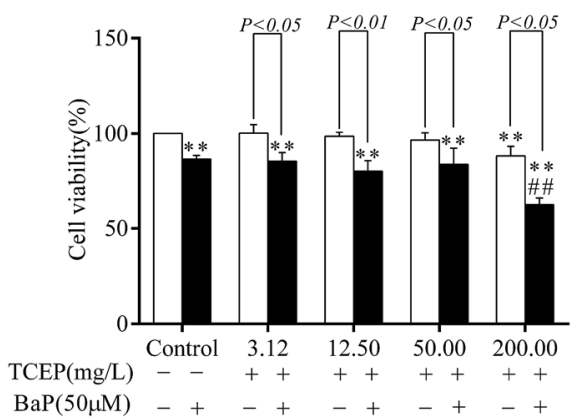

B

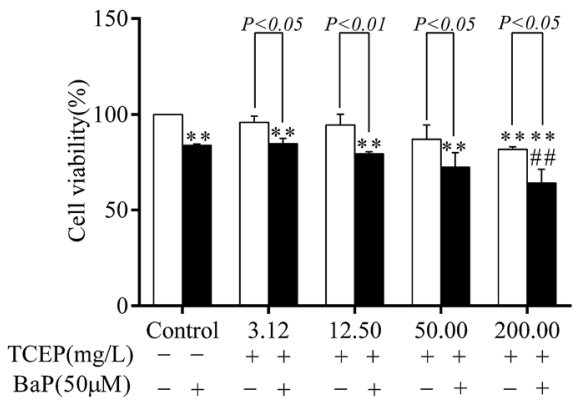

Fig. 1 Effects of co-treatment of TCEP and BaP on cell viability in HepG2 cells. Cells were treated with TCEP at the indicated concentrations $\left(3.12,12.5,50\right.$ and $\left.200 \mathrm{mg} \mathrm{L}^{-1}\right)$ alone, BaP $(50 \mu \mathrm{M})$ alone or TCEP plus BaP for $24(\mathrm{~A})$ and $48 \mathrm{~h}(\mathrm{~B})$. DMSO $(\mathrm{v} / \mathrm{v} 0.1 \%)$ served as the solvent control. Cell viability was measured by the MTT assay. The results were shown as the percentage of surviving cells compared with the control cells. Data were expressed as the mean \pm SD of at least three independent experiments. Statistical significance was determined by ANOVA and Dunnett's post hoc test $\left(* * P<0.01\right.$ vs. the control, ${ }^{\# \#} P<0.01$ vs. the group of BaP alone).

\subsection{Combined effects of TCEP and BaP on the cytokines}

To assess combined effect of TCEP and BaP on the expression of pro-inflammatory cytokines in HepG2 cells, we detected the mRNA expression of IL-6 and IL-8 in the HepG2 cells and the secretions of IL-6 and IL-8 proteins in the culture medium using qRT-PCR and ELISA assay, respectively. As shown in Fig. 2, no change was found in mRNA levels of IL- 6 and IL-8 in all the groups of TCEP alone at 24 and $48 \mathrm{~h}$ compared to the solvent control, but increased mRNA levels of IL- 6 and IL- 8 were found in all the co-treated groups with TCEP at the indicated concentration plus $50 \mu \mathrm{M} \mathrm{BaP}$ at 24 and $48 \mathrm{~h}$, compared to the solvent control and the corresponding groups of TCEP alone $(P<0.05$ or $P<0.01)$, except for IL-8 mRNA expression in the group of $3.12 \mathrm{mg} \mathrm{L}^{-1}$ TCEP plus $50 \mu \mathrm{M}$ BaP at $24 \mathrm{~h}$.

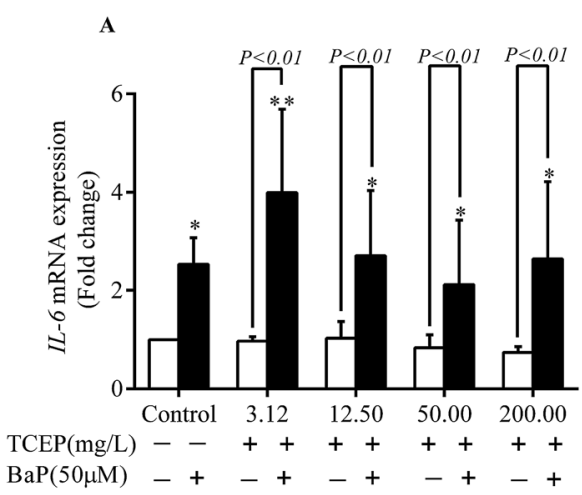

C

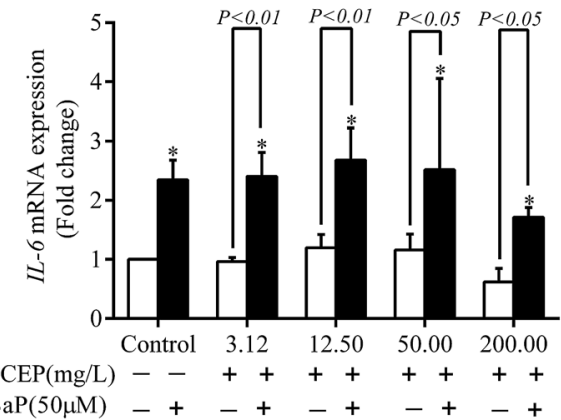

B

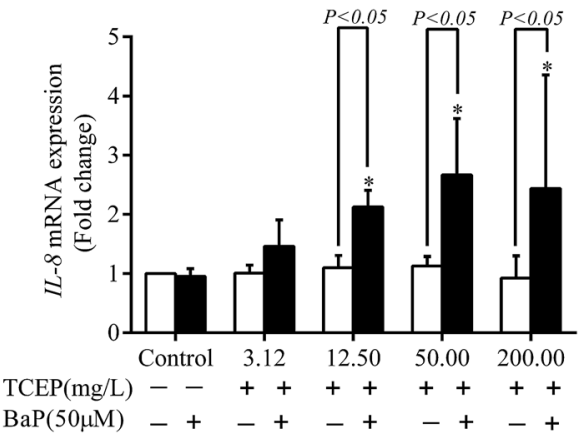

D

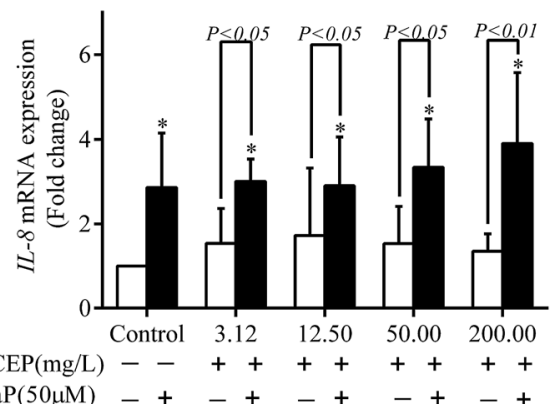

Fig. 2 Effects of co-treatment of TCEP and BaP on IL-6 and IL-8 expression at mRNA level in HepG2 cells. Total RNA was prepared for the quantitative real-time polymerase chain reaction analysis of IL-6 (A, C) and IL-8 (B, D) gene expression from HepG2 cells treated with TCEP at the indicated concentrations $\left(3.12,12.5,50\right.$ and $\left.200 \mathrm{mg} \mathrm{L}^{-1}\right)$ alone, BaP $(50 \mu \mathrm{M})$ alone or TCEP plus BaP for 24 (A, B) and $48 \mathrm{~h}(\mathrm{C}, \mathrm{D})$. Data were expressed as the mean \pm SD of three independent experiments. Statistical significance was determined by ANOVA and Dunnett's post hoc test $(* P<0.05, * * P<0.01$ vs. the control). 
Increased expression of IL-6 and IL-8 proteins in the culture media were detected, which was in consistent with the findings that the mRNA expression of IL-6 and IL-8 in HepG2 cells treated with TCEP alone, BaP alone or both of them at 24 and 48 h. As shown in Fig. 3, the amounts of IL-6 protein were significantly decreased in the groups of $200 \mathrm{mg} \mathrm{L}^{-1}$ TCEP alone at $24 \mathrm{~h}$ and 50 and $200 \mathrm{mg} \mathrm{L}^{-1}$ TCEP alone at $48 \mathrm{~h}(* * P<0.01)$, but the amounts of IL- 6 protein were increased in all the cotreated groups at 24 and $48 \mathrm{~h}$ compared to the solvent control $\left({ }^{* *} P<0.01\right)$. The amounts of IL-6 protein were increased in the groups of $12.5 \mathrm{mg} \mathrm{L}^{-1}$ TCEP plus $50 \mu \mathrm{M}$ BaP compared to the corresponding groups of $50 \mu \mathrm{M} \mathrm{BaP}$ alone at 24 and $48 \mathrm{~h}\left({ }^{\#} P<\right.$ 0.05 or $\left.{ }^{\# \#} P<0.01\right)$. Moreover, the amounts of IL-8 protein were increased in all the co-treated groups at $48 \mathrm{~h}$ compared to the solvent control $(* * P<0.01)$. Additionally, expression of IL- 6 and IL-8 protein were increased in all the co-treated groups compared to the corresponding groups of TCEP alone $(P<0.05$ or $P<0.01$ ), except for the expression of IL-8 protein in the group of $3.12 \mathrm{mg} \mathrm{L}^{-1}$ TCEP plus $50 \mu \mathrm{M} \mathrm{BaP}$ at $24 \mathrm{~h}$.

\subsection{Combined effect of TCEP and BaP on the regulators}

To explore whether the MAPK pathway was involved in the inflammatory response in HepG2 cells co-treated with TCEP and $\mathrm{BaP}$, we firstly treated HepG2 cells with TCEP alone at the indicated concentrations, $50 \mu \mathrm{M} \mathrm{BaP}$ alone or co-treatment of
TCEP plus BaP for 24 and $48 \mathrm{~h}$. As shown in Fig. 4A-D, the ratios of p-EGFR/EGFR were obviously increased in the groups of $50 \mu \mathrm{M}$ BaP alone and TCEP (3.12, 12.5 and $\left.50 \mathrm{mg} \mathrm{L}^{-1}\right)$ plus $50 \mu \mathrm{M} \mathrm{BaP}$ at 24 and $48 \mathrm{~h}$ compared to the solvent control $\left({ }^{*} P<0.05\right)$. The increases in the ratios of $\mathrm{p}$-EGFR/EGFR proteins were found in all the co-treated groups compared to the corresponding groups of TCEP alone, except for the group of $200 \mathrm{mg} \mathrm{L}{ }^{-1}$ TCEP plus $50 \mu \mathrm{M} \mathrm{BaP}$ at 24 and $48 \mathrm{~h}$. As shown in Fig. $4 \mathrm{~A}, \mathrm{~B}, \mathrm{E}$ and $\mathrm{F}$, the ratios of $\mathrm{p}-\mathrm{ERK} 1 / 2 / \mathrm{ERK} 1 / 2$ were obviously increased in all the co-treated groups at 24 and $48 \mathrm{~h}$, compared to the solvent control and corresponding groups of TCEP alone $(P<0.05$ or $P<0.01)$. No effect was found on the ratio of p-ERK1/2/ERK1/2 in the group of $50 \mu \mathrm{M}$ BaP alone compared to the solvent control. As shown in Fig. $4 \mathrm{~A}, \mathrm{~B}, \mathrm{G}$ and $\mathrm{H}$, the ratios of p-p38 MAPK/p38 MAPK were obviously increased in the group of $50 \mu \mathrm{M}$ BaP alone and all the co-treated groups at 24 and $48 \mathrm{~h}$ compared to the solvent control $\left({ }^{*} P<0.05\right)$. Additionally, the increased ratios of p-p38 MAPK/p38 MAPK were observed in the group of $3.12 \mathrm{mg} \mathrm{L}^{-1}$ TCEP plus $50 \mu \mathrm{M}$ BaP compared to the corresponding group of TCEP alone $(P<0.05)$.

\subsection{Regulation of EGFR and MAPK pathways in the inflammatory response}

After investigating effects of TCEP plus BaP on EGFR, ERK1/2 and p38 MAPK in HepG2 cells, we then consequently did the

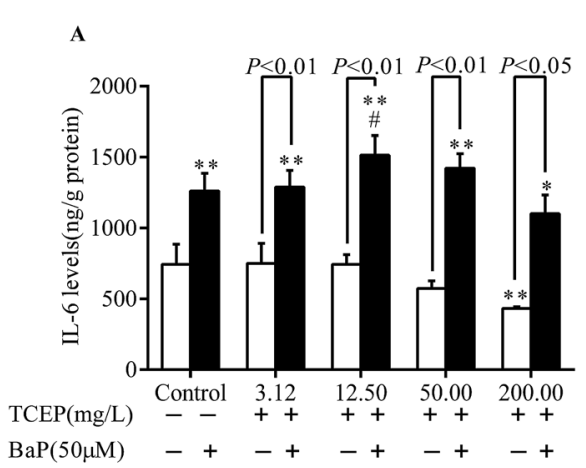

B
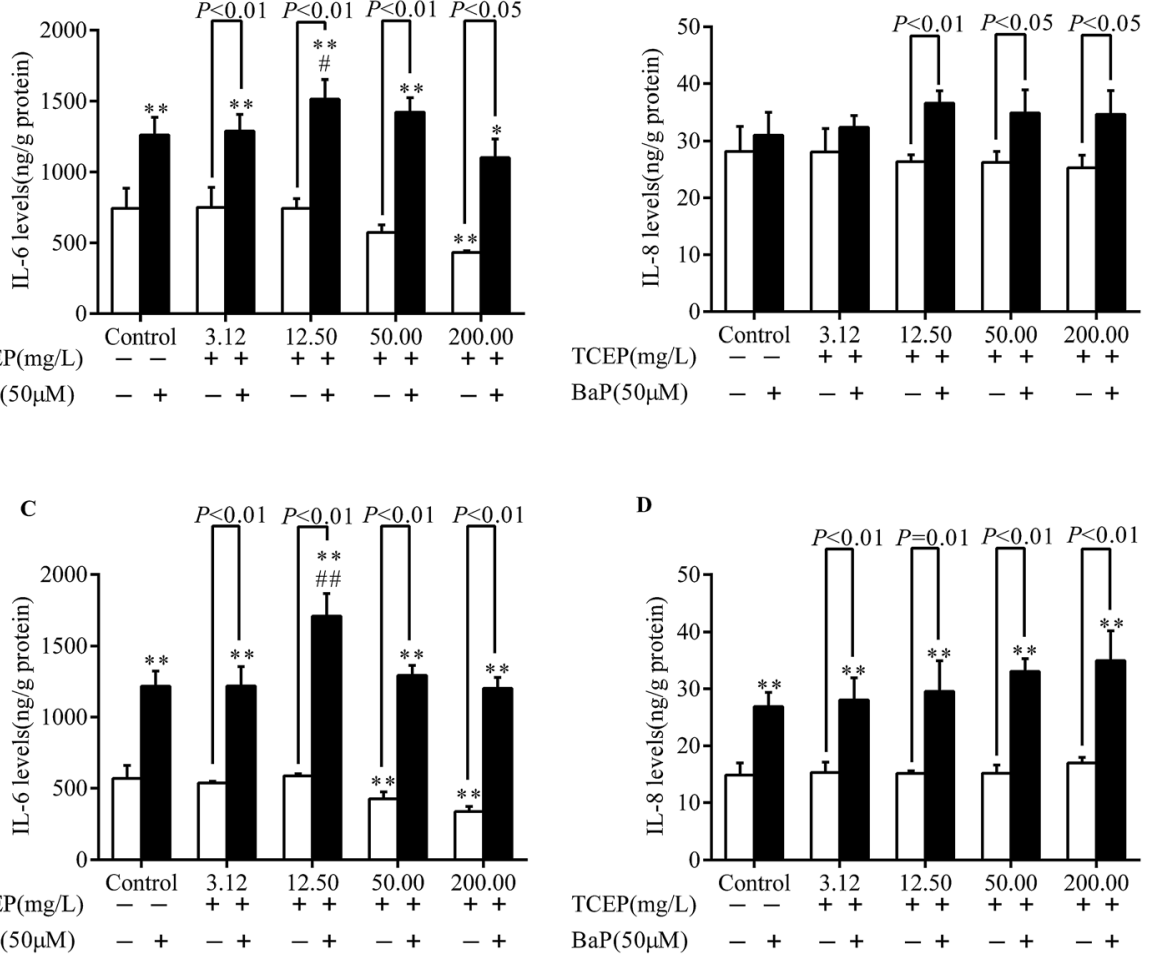

D

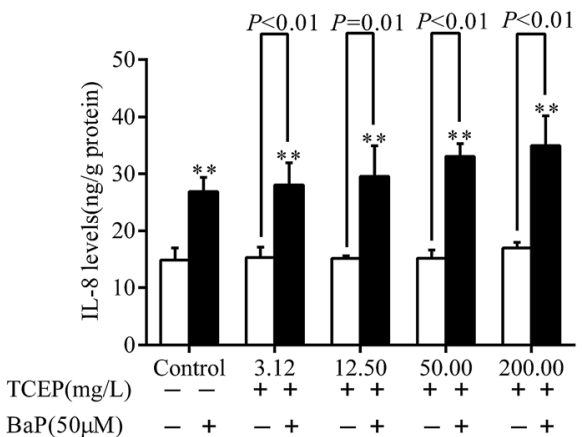

Fig. 3 Effects of co-treatment of TCEP and BaP on the productions of IL- 6 and IL- 8 in HepG 2 cells. Cells were treated with TCEP at the indicated concentrations $\left(3.12,12.5,50\right.$ and $\left.200 \mathrm{mg} \mathrm{L}^{-1}\right)$ alone, BaP $(50 \mu \mathrm{M})$ alone or TCEP plus BaP for $24(\mathrm{~A}, \mathrm{~B})$ and $48 \mathrm{~h}(\mathrm{C}, \mathrm{D})$. The levels of IL-6 (A, C) and IL-8 $(B, D)$ in the supernatants were quantified using ELISA Kits. Data were expressed as the mean \pm SD of three independent experiment. Statistical significance was determined by ANOVA and Dunnett's post hoc test $(* P<0.05, * * P<0.01 \mathrm{vs}$. the control, \#\# $P<0.01 \mathrm{vs}$. the group of BaP alone). 

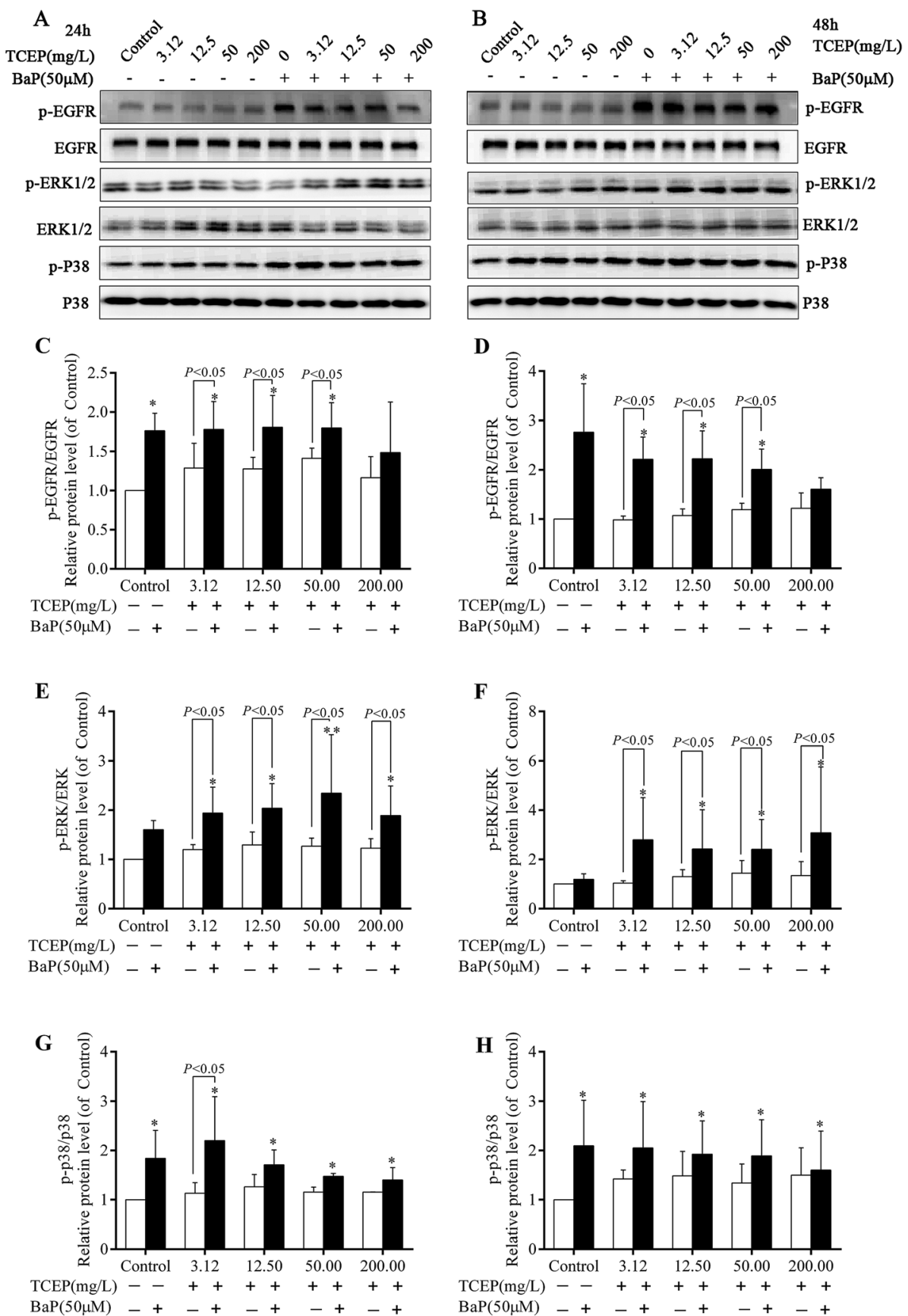

Fig. 4 Effects of co-treatment of TCEP and BaP on expression of p-EGFR, EGFR, p-ERK1/2, ERK1/2, p-p38 MAPK, p38 MAPK proteins in HepG2 cells. Cells were treated with TCEP at the indicated concentrations $\left(3.12,12.5,50\right.$ and $\left.200 \mathrm{mg} \mathrm{L}^{-1}\right)$ alone, BaP $(50 \mu \mathrm{M})$ alone or TCEP plus BaP for $24(A, C, E$ and $G$ ) and $48 \mathrm{~h}(\mathrm{~B}, \mathrm{D}, \mathrm{F}$ and $\mathrm{H}$ ). The expression of $\mathrm{p}$-EGFR, EGFR, p-ERK1/2, ERK1/2, p-p38 MAPK, p38 MAPK proteins were detected by Western blot. GAPDH expression was measured in parallel as the loading controls. Similar results were obtained in three independent experiments. (A and B) Representative images of Western blot bands; $(C-H)$ Densitometric data regarding the ratios of $p-E G F R / E G F R, p-E R K 1 / 2 / E R K 1 / 2$ and p-p38 MAPK/p38 MAPK were expressed as the mean \pm SD of three independent experiment. Statistical significance was determined by ANOVA and Dunnett's post hoc test $(* P<0.05, * * P<0.01$ vs. the control).

regulations of the EGFR, ERK1/2 and p38 MAPK pathways involved in inflammatory response in HepG2 cells co-treated with TCEP and BaP. The HepG2 cells were firstly incubated with U0126 (ERK1/2 inhibitor, $10 \mu \mathrm{M}$ ), SB203580 (p38 MAPK inhibitor, $10 \mu \mathrm{M}$ ) and AG1478 (EGFR inhibitor, $0.1 \mu \mathrm{M}$ ) for $1 \mathrm{~h}$ prior to the treatment of $50 \mathrm{mg} \mathrm{L^{-1 }}$ TCEP alone, $50 \mu \mathrm{M} \mathrm{BaP}$ alone or both of them, then IL-6 and IL-8 expression were measured by qRT-PCR and ELISA assay. As shown in Fig. 5A and $\mathrm{B}$, compared with the group of $50 \mathrm{mg} \mathrm{L}^{-1}$ TCEP plus $50 \mu \mathrm{M} \mathrm{BaP}$, U0126, SB203580 or AG1478 decreased the IL-6 mRNA expression by $55.57 \%, 69.89 \%$ and $44.81 \%$ in the each cotreatment group of $50 \mathrm{mg} \mathrm{L}^{-1}$ TCEP plus $50 \mu \mathrm{M} \mathrm{BaP}$, respectively; U0126, SB203580 or AG1478 decreased the IL-8 mRNA expression by $58.71 \%, 48.19 \%$ and $30.19 \%$ in the each cotreatment group of 


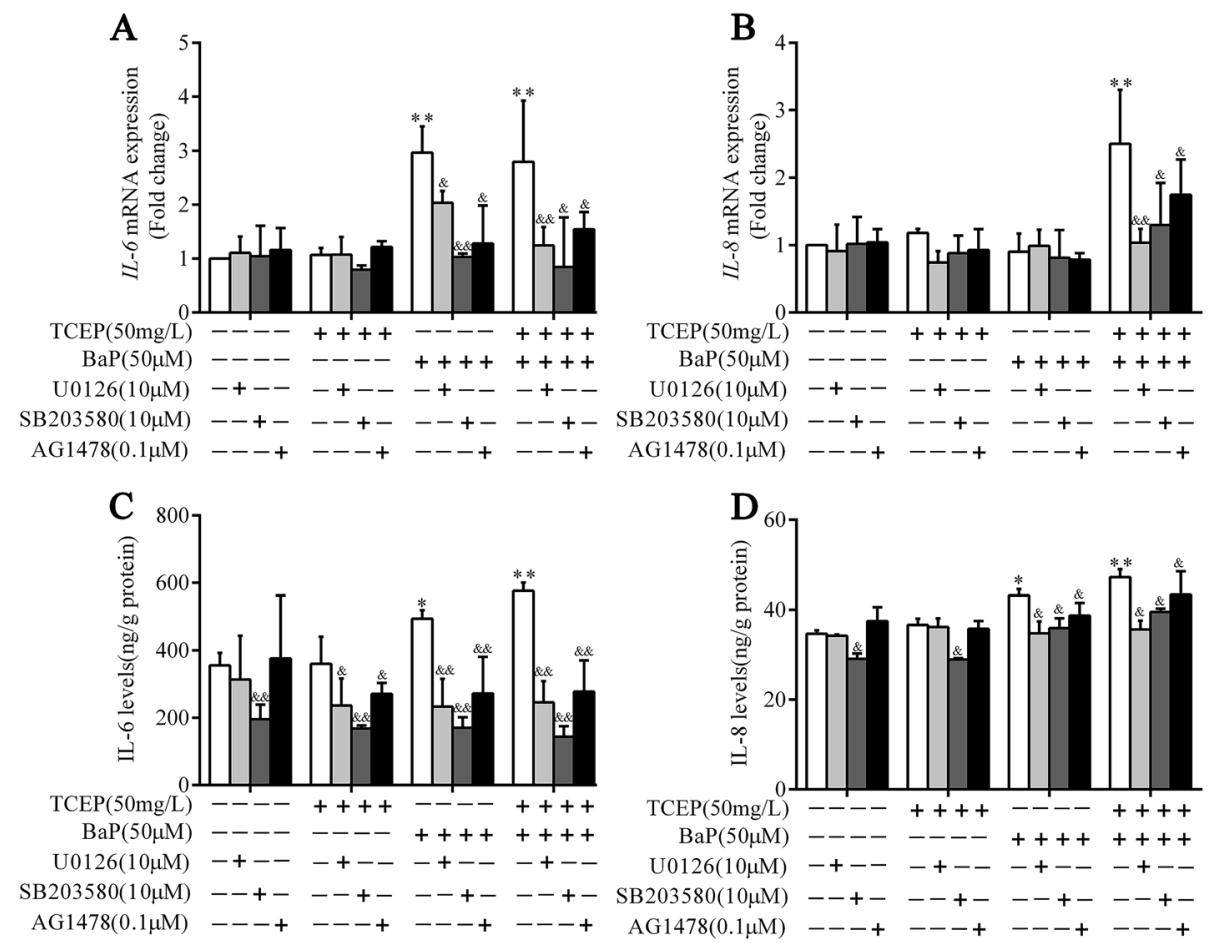

Fig. 5 Regulations of the EGFR, ERK1/2 and p38 MAPK pathways in IL- 6 and IL- 8 expression induced by TCEP plus BaP. Total RNA was prepared for real-time PCR analysis of IL-6 (A) and IL-8 (B) mRNA expression from HepG2 cells pretreated with AG1478, U0126 or SB203580 1 h prior to the incubation of $50 \mathrm{mg} \mathrm{L}^{-1}$ TCEP alone, $50 \mu \mathrm{M} \mathrm{BaP}$ alone or both of them for $24 \mathrm{~h}$. In parallel, expression of IL- 6 and IL- 8 proteins were detected by ELISA in the cells pretreated with AG1478, U0126 or SB203580 prior to the incubation of $50 \mathrm{mg} \mathrm{L}^{-1} \mathrm{TCEP}$ alone, $50 \mu \mathrm{M}$ BaP alone or both of them for $24 \mathrm{~h}$. Levels of IL-6 (C) and IL-8 (D) proteins in the supernatants were quantified using ELISA. Data were expressed as the mean \pm SD of three independent experiments. Statistical significance was determined by ANOVA and Dunnett's post hoc test $(* P<0.05, * * P<0.01$ vs. the control; ${ }^{8} P<0.05$, ${ }^{\&} \mathrm{P}<0.01 \mathrm{vs}$. the corresponding $50 \mathrm{mg} \mathrm{L}^{-1} \mathrm{TCEP}$ alone, $50 \mu \mathrm{M} \mathrm{BaP}$ alone or TCEP $\left(50 \mathrm{mg} \mathrm{L}{ }^{-1}\right) \mathrm{plus} \mathrm{BaP}(50 \mu \mathrm{M})$ group).

$50 \mathrm{mg} \mathrm{L} \mathrm{L}^{-1}$ TCEP plus $50 \mu \mathrm{M}$ BaP, respectively. As shown in Fig. 5C and D, compared with the group of $50 \mathrm{mg} \mathrm{L}^{-1}$ TCEP plus $50 \mu \mathrm{M}$ BaP, U0126, SB203580 or AG1478 decreased IL-6 protein expression by $57.36 \%, 75.05 \%$ and $51.83 \%$ in the each cotreatment group of $50 \mathrm{mg} \mathrm{L}^{-1}$ TCEP plus $50 \mu \mathrm{M} \mathrm{BaP}$, respectively; U0126, SB203580 or AG1478 decreased IL-8 protein expression by $24.56 \%, 16.27 \%$ and $8.28 \%$ in the each co-treatment group of with $50 \mathrm{mg} \mathrm{L}^{-1}$ TCEP plus $50 \mu \mathrm{M} \mathrm{BaP}$, respectively.

\subsection{Effect of EGFR inhibitor on ERK1/2 and p38 MAPK activated by TCEP plus BaP}

To determine whether the activation of p38 MAPK and ERK1/2 was attenuated by inhibitors of EGFR in HepG2 cells co-treated with TCEP and BaP, we performed western blot analysis on ERK1/2, and p38 MAPK expression in HepG2 cells incubated with $0.1 \mu \mathrm{M}$ AG1478 (EGFR inhibitor) for $1 \mathrm{~h}$ prior to the treatment of $50 \mathrm{mg} \mathrm{L}^{-1}$ TCEP alone, $50 \mu \mathrm{M}$ BaP alone or both of them for $24 \mathrm{~h}$. As shown in Fig. 6A-C, compared with the group of $50 \mathrm{mg} \mathrm{L}^{-1}$ TCEP plus $50 \mu \mathrm{M} \mathrm{BaP}$, AG1478 decreased the ratios of p-EGFR/EGFR and p-ERK/ERK by $41.03 \%$ and $23.42 \%$ in the groups of $50 \mu \mathrm{M} \mathrm{BaP}$ alone and $50 \mathrm{mg} \mathrm{L}^{-1} \mathrm{TCEP}$ plus $50 \mu \mathrm{M} \mathrm{BaP}$, respectively $\left({ }^{\&} P<0.05\right)$, but no effect on the ratio of p-p38 MAPK/ p38 MAPK was found in the groups of $50 \mu \mathrm{M}$ BaP alone and $50 \mathrm{mg} \mathrm{L}^{-1}$ TCEP plus $50 \mu \mathrm{M}$ BaP (Fig. 6A and D).

\section{Discussion}

TCEP was ubiquitously existed in the environment and biota. The detected TCEP concentrations in drinking water samples (0-500 $\left.\mathrm{ng} \mathrm{L}{ }^{-1}\right),{ }^{30}$ indoor dust samples $\left(220-6900 \mathrm{ng} \mathrm{g}^{-1}\right),{ }^{31}$ human breast milk samples $\left(0-512 \mathrm{ng} \mathrm{g}^{-1}\right)^{32}$ were reported. Human exposed to TCEP mainly through inhalation and dermal contact in the occupational and natural environments. European Union reported that personal TCEP exposure levels via the dermal contact route ranged from 42 to $420 \mathrm{mg} \mathrm{day}^{-1}$ for the unprotected workers who engaged in TCEP production. ${ }^{6}$ Thus, the concentrations ( 3.12 to $200.00 \mathrm{mg} \mathrm{L}^{-1}$ ) of TCEP were used in this study, which were in accordance with those our previous studies. ${ }^{33-35}$ After comparing the combined effect of TCEP (3.12, $12.5,50$ and $200 \mathrm{mg} \mathrm{L}^{-1}$ ) plus $30 \mu \mathrm{M}$ BaP or $50 \mu \mathrm{M}$ BaP on cell viability, respectively, we chose $50 \mu \mathrm{M}$ BaP for further study because no significant difference in cell viability were found in all the co-treated groups of $30 \mu \mathrm{M} \mathrm{BaP}$ and TCEP at the indicated concentrations, compared to the corresponding groups of TCEP alone (data not shown). Moreover, the dose of BaP $(50 \mu \mathrm{M})$ had been used in previous studies. ${ }^{36,37}$ Considering that the accumulated human exposure to PAHs through inhalation, ingestion and dermal contact, and their lipophilicity and undegradable characteristics, $50 \mu \mathrm{M} \mathrm{BaP}$ was used in this study, the used concentration was higher than the concentrations found in the environments. 
A

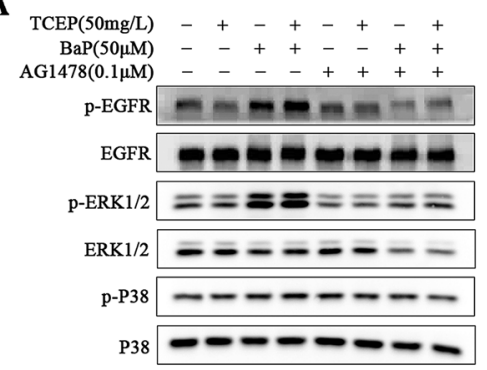

C

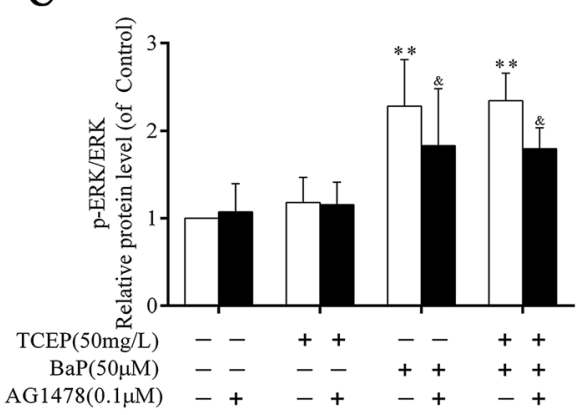

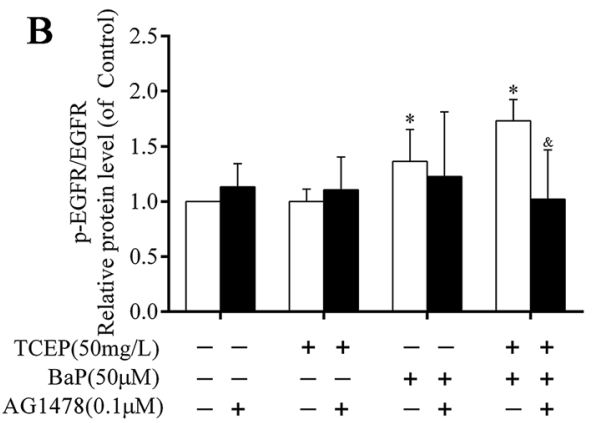

D

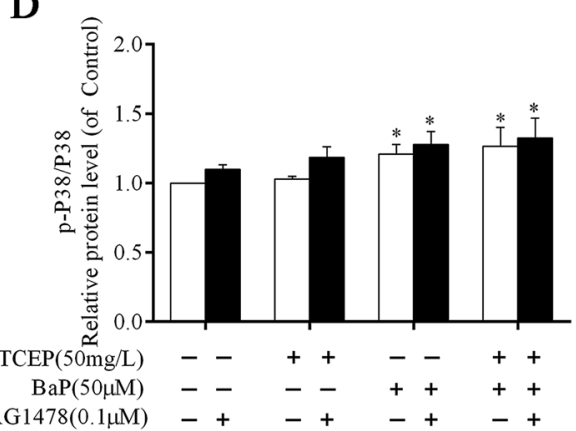

Fig. 6 Effects of AG1478 on the ERK1/2 and p38 MAPK pathways activated by TCEP plus BaP. HepG2 cells pretreated with AG1478 $1 \mathrm{~h}$ prior to the incubation of $50 \mathrm{mg} \mathrm{L}^{-1}$ TCEP alone, $50 \mu \mathrm{M} \mathrm{BaP}$ alone or both of them for $24 \mathrm{~h}$. Expression of p-EGFR, EGFR, p-ERK1/2, ERK1/2, p-p38 MAPK, p38 MAPK proteins were detected by Western blot. GAPDH expression was measured in parallel as the loading controls. Similar results were obtained in three independent experiments. (A) Representative images of Western blot bands; (B-D) densitometric analyses of the ratios of $p$ EGFR/EGFR, p-ERK1/2/ERK1/2 and p-p38 MAPK/p38 MAPK from three independent experiments. Data were expressed as the mean \pm SD of three independent experiments. Statistical significance was determined by ANOVA and Dunnett's post hoc test $(* P<0.05, * * P<0.01$ vs. the control; ${ }^{\&} P<0.05$, \&\& $P<0.01$ vs. the corresponding $50 \mathrm{mg} \mathrm{L}^{-1} \mathrm{TCEP}$ alone, $50 \mu \mathrm{M} \mathrm{BaP}$ alone or TCEP $\left.\left(50 \mathrm{mg} \mathrm{L} \mathrm{L}^{-1}\right) \mathrm{plus} \mathrm{BaP}(50 \mu \mathrm{M}) \mathrm{group}\right)$.

In the present study, we found that the decreased cell viability in the co-treated cells were more severer than that in the groups of TCEP alone or BaP alone. The results suggested that TCEP and BaP affect the cell viability in a synergistic manner, implying that TCEP could increase BaP-induced the decrease in the cell viability. We did not observe significant changes in expression of IL- 6 and IL-8 both at the mRNA and proteins levels in HepG2 cells treated with TCEP alone. However, only BaP and co-treatment of TCEP and BaP increased expression of IL- 6 and IL-8 both at the mRNA and protein levels in a dose-independent manner. The results suggested that $\mathrm{BaP}$ played the critical role in the additive effect of the inflammatory response in HepG2 cells co-treated with TCEP and BaP. These findings are similar to those of the previous study on the interaction between $\mathrm{BaP}$ and metals. ${ }^{12}$ This may be explained that $\mathrm{BaP}$ is of the toxic characteristics of stronger mutagenic, carcinogenic and pro-oxidative agent. ${ }^{38}$

A previous study reported that treatment of $20 \mu \mathrm{M} \mathrm{BaP}$ contributed to higher levels of $\mathrm{IL}-1 \beta$ and TNF- $\alpha$ protein compared to the control group in human lung adenocarcinoma A549 cell. ${ }^{39}$ Whereas, BaP at the lower concentrations of 0.1 to $10 \mu \mathrm{M}$ significantly induced expression of IL-6 and IL-8 proteins in human airway epithelial cells (BEAS-2B). ${ }^{40}$ The reason for these inconsistent results indicated that diverse cell types and the used doses may lead to differential inflammation consequences. As the available information about the combined effects of TCEP and BaP is limited, the underlying mechanism on the inflammation induced by these coexisted compounds need to be further investigated.

The results from the previous studies showed that endocrinedisrupting chemicals such as benzo (ghi) perylene and bisphenol A were associated with the reduction of the cell viability or induction of inflammatory response by the EGFR-dependent signaling pathway. ${ }^{14,41}$ Our results exhibited that EGFR was activated in HepG2 cells co-treated with TCEP and BaP. Additionally, the EGFR inhibitor AG1478 inhibited the expression of IL-6 and IL-8 at mRNA and proteins levels, suggesting that TCEP plus BaP stimulated inflammatory response in the HepG2 cells by the EGFR signaling pathway. Thus, we further observed the downstream effectors of the EGFR signaling pathway to elucidate the underlying mechanisms of the inflammatory response in HepG2 cell treated with TCEP plus BaP.

Three major MAPKs (ERK1/2, p38 MAPK and JNK) have been implicated as the classic mediators of the signal pathways that respond to cellular stress and inflammation. ${ }^{42}$ We investigated whether the phosphorylation of ERK1/2, p38 MAPK and JNK play crucial roles in inflammatory response induced by TCEP plus BaP in HepG2 cells. The findings found that the inhibitors of ERK1/2 (U0126) and p38 MAPK (SB203580) could partially inhibit IL-6 and IL-8 mRNA and protein expression induced by TCEP plus BaP in HepG 2 cells, indicating that the ERK1/2 and p38 MAPK were of the crucial functions in the inflammatory process. JNK was a stress-activated protein kinase, but we did not detect the phosphorylated JNK in the cells (data not shown). This kind of 


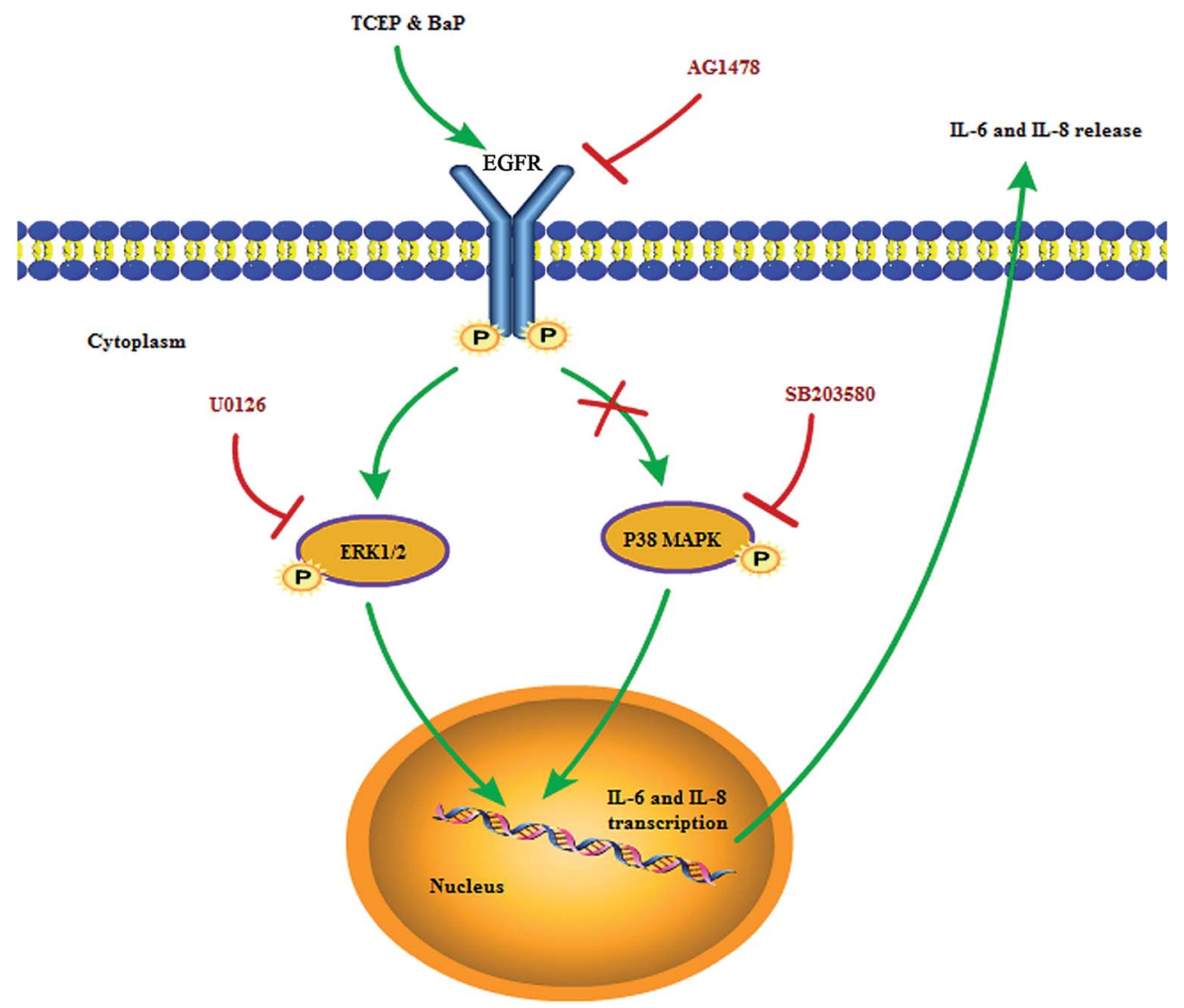

Fig. 7 The predictive mechanism for inflammatory response in HepG2 cells treated with TCEP plus BaP.

difference in the expression of MAPK family member in response to environmental pollutants may be related to cell type-specific, ${ }^{\mathbf{4 3}}$ which might explain our findings that the activation of ERK1/2 and p38 MAPK, but not JNK, involved in inflammatory response induced by TCEP plus BaP. We confirmed that AG1478 inhibited the ERK1/2 expression, but not p38 MAPK. These results suggested that TCEP plus BaP induced the activation of the EGFRERK1/2 signaling pathway (Fig. 7).

In summary, co-treatment of TCEP and BaP induced inflammatory response in HepG2 cells in a synergistic manner, which was partially mediated by the EGFR-ERK1/2 signaling pathways. Future study is warranted to investigate transcription factors, such as nuclear factor-kappa B and signal transducers and activators of transcription 3, involved in the IL-6 and IL-8 expression and the regulations of other signaling pathway in response to cellular inflammation induced by TCEP plus BaP.

\section{Conflicts of interest}

The authors declare that there is no conflict of interest.

\section{Abbreviations}

\section{BaP Benzo (a) pyrene}

DMSO Dimethyl sulfoxide

EGFR Epidermal growth factor receptor
ERK Extracellular signal regulated kinase

FBS Fetal bovine serum

IL Interleukin

MTT 3-(4,5-Dimethyithiazol-2-yl)-2,5-diphenyl-tetrazolium bromide

PBS Phosphate buffer solution

qRT- Quantitative real-time polymerase chain reaction

PCR

TCEP Tris(2-chloroethyl)phosphate

\section{Acknowledgements}

This work was financially supported by the National Natural Science Foundations of China (Grants No. 81273023 and 81472947).

\section{References}

1 IARC, Some non-heterocyclic polycyclic aromatic hydrocarbons and some related exposures, International Agency for Research on Cancer, 2010.

2 R. Sinha, M. Kulldorff, M. J. Gunter, P. Strickland and N. Rothman, Cancer Epidemiol., Biomarkers Prev., 2005, 14, 2030.

3 A. A. Peverly, Y. Ma, M. Venier, Z. Rodenburg, S. N. Spak, K. C. Hornbuckle and R. A. Hites, Environ. Sci. Technol., 2015, 49, 5371-5379. 
4 D. A. Alvarez, K. A. Maruya, N. G. Dodder, W. Lao, E. T. Furlong and K. L. Smalling, Mar. Pollut. Bull., 2014, 81, 347-354.

5 L. A. Henriquez-Hernandez, D. Montero, M. Camacho, R. Gines, L. D. Boada, B. Ramirez Bordon, P. F. Valeron, M. Almeida-Gonzalez, M. Zumbado, R. Haroun and O. P. Luzardo, Sci. Total Environ., 2017, 581-582, 199-208.

6 EU, European Union Risk Assessment Report, Tris(2-chloroethyl) phosphate, TCEP European Commission, Dortmund, 2009.

7 J. Q. Ma, C. M. Liu, Z. H. Qin, J. H. Jiang and Y. Z. Sun, Environ. Toxicol. Pharmacol., 2011, 31, 460-468.

8 R. Yanagisawa, E. Koike, T.-T. Win-Shwe, T. Ichinose and H. Takano, J. Appl. Toxicol., 2016, 36, 1496-1504.

9 A. Araki, I. Saito, A. Kanazawa, K. Morimoto, K. Nakayama, E. Shibata, M. Tanaka, T. Takigawa, T. Yoshimura, H. Chikara, Y. Saijo and R. Kishi, Indoor Air, 2014, 24, 3-15. 10 Q. Shi, R. W. L. Godschalk and F. J. van Schooten, Mutat. Res., Rev. Mutat. Res., 2017, 774, 12-24.

11 A. A. Peverly, C. O'Sullivan, L.-Y. Liu, M. Venier, A. Martinez, K. C. Hornbuckle and R. A. Hites, Chemosphere, 2015, 134, 380-386.

12 S. Muthusamy, C. Peng and J. C. Ng, Chemosphere, 2016, 165, 41-51.

13 S. C. Jeong, Y. Cho, M. K. Song, E. Lee and J. C. Ryu, Environ. Toxicol., 2017, 32, 1628-1636.

14 S. J. Sauer, M. Tarpley, I. Shah, A. V. Save, H. K. Lyerly, S. R. Patierno, K. P. Williams and G. R. Devi, Carcinogenesis, 2017, 38, 252-260.

15 S. D. McCullough, K. E. Duncan, S. M. Swanton, L. A. Dailey, D. Diaz-Sanchez and R. B. Devlin, Am. J. Respir. Cell Mol. Biol., 2014, 51, 426-435.

16 M. Gao, Y. Q. Zhan, M. Yu, C. H. Ge, C. Y. Li, J. H. Zhang, X. H. Wang, Z. Q. Ge and X. M. Yang, Cell. Signalling, 2014, 26, 2161-2166.

17 A. C. Fitzgerald, C. Peyton, J. Dong and P. Thomas, Biol. Reprod., 2015, 93, 1-11.

18 Y. Saito, J. Haendeler, Y. Hojo, K. Yamamoto and B. C. Berk, Mol. Cell. Biol., 2001, 21, 6387-6394.

19 A. S. Randi, M. S. Sanchez, L. Alvarez, J. Cardozo, C. Pontillo and D. L. K. de Pisarev, Toxicol. Lett., 2008, 177, 116-122.

20 B. Bhushan, M. M. Haynes, W. M. Mars, A. Orr, W. C. Bowen, S. Paranjpe and G. K. Michalopoulos, FASEB J., 2017, 31, 531-536.

21 Y. Zhan, Y. Chen, R. Liu, H. Zhang and Y. Zhang, Arch. Pharmacal Res., 2014, 37, 1086-1095.

22 Q. Fang, C. Zou, P. Zhong, F. Lin, W. Li, L. Wang, Y. Zhang, C. Zheng, Y. Wang and X. Li, Oncotarget, 2016, 7, 2436124373.

23 S. P. Faux, T. Tai, D. Thorne, Y. Xu, D. Breheny and M. Gaca, Biomarkers, 2009, 14, 90-96.

24 D. H. Phillips, Nature, 1983, 303, 468-472.
25 J. M. Choi, S. J. Oh, S. Y. Lee, J. H. Im, J. M. Oh, C. S. Ryu, H. C. Kwak, J.-Y. Lee, K. W. Kang and S. K. Kim, Arch. Pharmacal Res., 2015, 38, 691-704.

26 S. C. Ramaiahgari, M. W. den Braver, B. Herpers, V. Terpstra, J. N. Commandeur, B. van de Water and L. S. Price, Arch. Toxicol., 2014, 88, 1083-1095.

27 N. Wei, X. Feng, Z. Xie, Y. Zhang and Y. Feng, Toxicol. In Vitro, 2017, 42, 86-92.

28 Y. Zhou, S. Zhang, S. Deng, C. Dai, S. Tang, X. Yang, D. Li, K. Zhao and X. Xiao, Toxicol. Mech. Methods, 2016, 26, 11-21.

29 M.-F. Lee, C.-Y. Chan, H.-C. Hung, I. T. Chou, A. S. Yee and C.-Y. Huang, Oral Oncol., 2013, 49, 129-135.

30 M. J. Benotti, R. A. Trenholm, B. J. Vanderford, J. C. Holady, B. D. Stanford and S. A. Snyder, Environ. Sci. Technol., 2009, 43, 597-603.

31 A. Bradman, R. Castorina, F. Gaspar, M. Nishioka, M. Colón, W. Weathers, P. P. Egeghy, R. Maddalena, J. Williams, P. L. Jenkins and T. E. McKone, Chemosphere, 2014, 116, 61-66.

32 J.-W. Kim, T. Isobe, M. Muto, N. M. Tue, K. Katsura, G. Malarvannan, A. Sudaryanto, K.-H. Chang, M. Prudente, P. H. Viet, S. Takahashi and S. Tanabe, Chemosphere, 2014, 116, 91-97.

33 W. Zhang, Y. Zhang, J. Hou, T. Xu, W. Yin, W. Xiong, W. Lu, H. Zheng, J. Chen and J. Yuan, Environ. Toxicol. Pharmacol., 2017, 56, 68-75.

34 W. Zhang, Y. Zhang, T. Xu, Z. Wang, J. Wang, W. Xiong, W. Lu, H. Zheng and J. Yuan, Toxicol. Res., 2016, 5, 461-470.

35 W. Zhang, Y. Zhang, Z. Wang, T. Xu, C. Huang, W. Yin, J. Wang, W. Xiong, W. Lu, H. Zheng and J. Yuan, J. Appl. Toxicol., 2016, 36, 914-924.

36 J. An, L. Yin, Y. Shang, Y. Zhong, X. Zhang, M. Wu, Z. Yu, G. Sheng, J. Fu and Y. Huang, Mutat. Res., 2011, 721, 192198.

37 W. Wei, X. F. Li, X. N. Li, X. M. Chen, A. L. Liu and W. Q. Lu, Environ. Toxicol., 2012, 27, 316-320.

38 B. O. Ajayi, I. A. Adedara and E. O. Farombi, Food Chem. Toxicol., 2016, 95, 42-51.

39 S. T. Chan, C. H. Chuang, C. L. Yeh, J. W. Liao, K. L. Liu, M. J. Tseng and S. L. Yeh, J. Nutr. Biochem., 2012, 23, 179185.

40 P. H. Chowdhury, G. Kitamura, A. Honda, T. Sawahara, T. Hayashi, W. Fukushima, H. Kudo, S. Ito, S. Yoshida, T. Ichinose, K. Ueda and H. Takano, Environ. Toxicol., 2017, 32, 2172-2181.

41 K. F. Ho, C. C. Chang, L. Tian, C. S. Chan, B. A. Musa Bandowe, K. H. Lui, K. Y. Lee, K. J. Chuang, C. Y. Liu, Z. Ning and H. C. Chuang, Environ. Pollut., 2016, 218, 1262-1269.

42 Y. W. Ki, J. H. Park, J. E. Lee, I. C. Shin and H. C. Koh, Toxicol. Lett., 2013, 218, 235-245.

43 B. A. Mercer and J. M. D'Armiento, Int. J. Chronic Obstruct. Pulm. Dis., 2006, 1, 137-150. 